\title{
Structure Elucidation of Fungal Sespendole, an Inhibitor of Lipid Droplet Synthesis in Macrophages
}

\author{
Ryuji Uchida, Yong-Pil Kim, Tohru Nagamitsu, Hiroshi Tomoda, Satoshi Ōmura
}

Received: February 22, 2006 / Accepted: May 20, 2006

(C) Japan Antibiotics Research Association

\begin{abstract}
A new fungal metabolite named sespendole was isolated as an inhibitor of lipid droplet synthesis in mouse macrophages from the culture broth of the fungal strain Pseudobotrytis terrestris FKA-25. The structure and stereochemistry of sespendole were elucidated by spectroscopic studies including various NMR spectral analyses, exciton chirality experiments and the modified Mosher method. Sespendole was found to possess a new indolosesquiterpene skeleton modified with two isoprenes.
\end{abstract}

Keywords sespendole, indolosesquiterpene, fungal metabolites, structure elucidation

\section{Introduction}

Sespendole (1, Fig. 1) produced by Pseudobotrytis terrestris FKA-25 [1] is a potent inhibitor of lipid droplet synthesis in macrophages. The fermentation, isolation and biological activities of $\mathbf{1}$ were described previously [2].

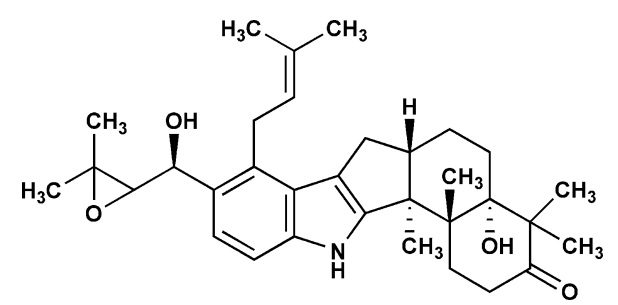

Fig. 1 Structure of sespendole (1).
In this report, we describe the structure elucidation of $\mathbf{1}$ and show that $\mathbf{1}$ possesses an indolosesquiterpene core with two additional isoprenyl side chains. A number of indoloditerpenes have been reported from fungi [3], such as paspalicine [4], paxilline [5, 6], janthitrems [7, 8], lolitrems [9] and penitrems [10 12] and terpendoles [13 15]. To our knowledge, $\mathbf{1}$ is the first microbial metabolite having an indolosesquiterpene core. The biosynthesis of $\mathbf{1}$ was reported previously [16].

\section{Results and Discussion}

Physico-chemical Properties

The physico-chemical properties of $\mathbf{1}$ are summarized in Table 1. Compound $\mathbf{1}$ is a colorless amorphous solid, and is soluble in chloroform, methanol, acetone and ethyl acetate. The molecular formula was revealed to be $\mathrm{C}_{33} \mathrm{H}_{45} \mathrm{NO}_{4}$ by HR-EI-MS ( $\mathrm{m} / z$ 519.3339; calcd. 519.3349). The UV spectrum exhibited characteristic absorption maxima at 239 and $288 \mathrm{~nm}$ in methanol, suggesting the presence of an indole moiety in the structure. The IR spectrum showed $-\mathrm{OH}$ and/or $-\mathrm{NH}$ absorption at $3426 \mathrm{~cm}^{-1}$ and carbonyl absorption at $1693 \mathrm{~cm}^{-1}$.

\section{Structure of Sespendole}

The ${ }^{1} \mathrm{H}$ and ${ }^{13} \mathrm{C}$ NMR spectra of $\mathbf{1}$ showed 45 protons and 33 carbons in pyridine- $d_{5}$ as shown in Table 2 . The carbon signals were classified into 8 methyl, 6 methylene, 6 methine, and 13 quaternary carbons by analysis of the
H. Tomoda (Corresponding author), R. Uchida, T. Nagamitsu: School of Pharmacy, Kitasato University, 5-9-1 Shirokane, Minato-ku, Tokyo 108-8641, Japan,

E-mail: tomodah@pharm.kitasato-u.ac.jp
Y.-P. Kim, S. Ōmura: Kitasato Institute for Life Sciences, Kitasato University and The Kitasato Institute, 5-9-1 Shirokane, Minato-ku, Tokyo 108-8641, Japan 
Table 1 Physico-chemical properties of $\mathbf{1}$

\begin{tabular}{ll}
\hline Appearance & Colorless amorphous solid \\
Molecular weight & 519 \\
Molecular formula & $\mathrm{C}_{33} \mathrm{H}_{45} \mathrm{NO}_{4}$ \\
$\mathrm{HREI}$-MS & \\
$\quad$ calcd & 519.3339 for $\mathrm{C}_{33} \mathrm{H}_{45} \mathrm{NO}_{4}$ \\
$\quad$ found & 519.3349 \\
UV $\lambda_{\text {max }} \mathrm{nm}(\varepsilon)$ in MeOH & $239(37,900), 288(8,800)$ \\
IR $v_{\text {max }} \mathrm{cm}^{-1}(\mathrm{KBr})$ & $3426,2929,1693,1456,1378$ \\
Optical Rotation & {$[\alpha]_{D}^{23}-18.0^{\circ}(c 0.1, \mathrm{MeOH})$} \\
Solubility & \\
$\quad$ soluble & $\mathrm{CHCl}_{3}, \mathrm{MeOH}, \mathrm{Acetone}, \mathrm{EtOAc}$ \\
insoluble & $\mathrm{Hexane}_{2} \mathrm{H}_{2} \mathrm{O}$ \\
\hline
\end{tabular}

DEPT spectra. The connectivity of proton and carbon atoms was established according to the ${ }^{13} \mathrm{C}-{ }^{1} \mathrm{H}$ HMQC spectra. As shown by bold lines in Fig. 2, five partial structures composed of I $\left(-\mathrm{CH}_{2}-\mathrm{CH}_{2}-\right)$, II $\left(-\mathrm{CH}_{2}-\mathrm{CH}_{2}-\right.$ $\left.\mathrm{CH}-\mathrm{CH}_{2}-\right)$, III $\left(-\mathrm{CH}_{2}-\mathrm{CH}=\right)$, IV $(-\mathrm{CH}-\mathrm{CH}-)$ and $\mathrm{V}$ $(-\mathrm{CH}=\mathrm{CH}-)$ were deduced from the ${ }^{1} \mathrm{H}-{ }^{1} \mathrm{H}$ COSY spectra. The ${ }^{13} \mathrm{C}-{ }^{1} \mathrm{H}$ long-range couplings of ${ }^{2} J$ and ${ }^{3} J$ in the HMBC spectra (Fig. 2) proved the presence of the following linkages. 1) The cross peaks from $\mathrm{H} 18(\delta 7.59)$ to $\mathrm{C} 16(\delta$ $131.6)$ and $\mathrm{C} 20(\delta 141.1)$, and from $\mathrm{H} 19(\delta 7.48)$ to $\mathrm{C} 15$ ( $\delta$ $126.5)$ and $C 17(\delta$ 130.2) suggested the presence of a 1,2,3,4-tetrasubstituted benzene ring that is shown in the partial structure V. The coupling constant $(8.5 \mathrm{~Hz})$ observed between $\mathrm{H} 18$ and H19 supported the possibility that they are in the ortho position of the benzene ring. The longrange couplings from $\mathrm{NH}(\delta 11.46)$ to $\mathrm{C} 2(\delta 154.5), \mathrm{C} 14$ $(\delta$ 116.6), $\mathrm{C} 15$ and $\mathrm{C} 20$ showed that a pyrole ring is attached to the benzene ring, thus revealing the presence of a 2,3,4,5-tetrasubstituted indole moiety. The presence of an indole moiety was also supported by the UV spectrum (absorption maxima at 239 and $288 \mathrm{~nm}$ ) and the fragment ion peak ( $m / z 113)$ in EI-MS (Fig. 3). 2) The long-range couplings from $\mathrm{H}_{3} 28(\delta 1.83)$ and $\mathrm{H}_{3} 29(\delta 1.65)$ to $\mathrm{C} 26(\delta$ $126.5)$ and from $\mathrm{H}_{2} 25(\delta 4.29,4.07)$ to $\mathrm{C} 27$ ( $\delta$ 131.2) suggested the presence of a 2-isopentenyl residue as shown in the partial structure III, which was supported by the fragment ion peak ( $m / z$ 69) in EI-MS (Fig. 3). Furthermore, long-range couplings were observed from $\mathrm{H}_{2} 25$ to $\mathrm{C} 15$ and $\mathrm{C} 17$ and from $\mathrm{H} 26$ to $\mathrm{C} 16$, suggesting that the 2isopentenyl residue is connected to $\mathrm{C} 16$ of the indole moiety. 3) The long-range couplings from $\mathrm{H}_{3} 33(\delta 1.39)$ and $\mathrm{H}_{3} 34(\delta 1.37)$ to $\mathrm{C} 31(\delta 69.5)$ and $\mathrm{C} 32(\delta 58.7)$, from $\mathrm{H} 30(\delta 5.32)$ to $\mathrm{C} 32$ and from the $\mathrm{OH} 30(\delta 7.18)$ to $\mathrm{C} 31$ suggested the presence of an isopentanyl unit as designated in the partial structure IV. Furthermore, the presence of an epoxy group at the $\mathrm{C} 31,32$-positions was inferred from the molecular formula, the chemical shifts of the ${ }^{1} \mathrm{H}$ and ${ }^{13} \mathrm{C}$ NMR signals of these positions and the relatively large ${ }^{1} J_{\mathrm{CH}}$ value for $\mathrm{C} 31\left({ }^{1} J_{\mathrm{C}-31, \mathrm{H}-31}=167 \mathrm{~Hz}\right)$. Long-range couplings were observed from $\mathrm{OH} 30$ to $\mathrm{C} 17$, from $\mathrm{H} 30$ to $\mathrm{C} 16$ and $\mathrm{C} 18$, from $\mathrm{H} 18$ to $\mathrm{C} 30$ and from $\mathrm{H} 31$ to $\mathrm{C} 17$, suggesting that the isopentanyl unit is connected to $\mathrm{C} 17$ of the indole moiety. 4) The long-range couplings from $\mathrm{H}_{2} 13(\delta 2.76$, $3.07)$ to $\mathrm{C} 2$ and $\mathrm{C} 3(\delta 53.5)$, from $\mathrm{H} 12(\delta 2.98)$ to $\mathrm{C} 14$ and $\mathrm{C} 2$, and from $\mathrm{H}_{3} 21(\delta 1.75)$ to $\mathrm{C} 2, \mathrm{C} 3$ and $\mathrm{C} 12$ suggested that the cyclopentene ring A sharing the partial structure II is attached to the indole moiety. 5) The long-range couplings from $\mathrm{H}_{2} 11(\delta 2.20,1.70)$ to $\mathrm{C} 3$ and $\mathrm{C} 9(\delta 80.9)$, from $\mathrm{H} 10(\delta 1.98,1.94), \mathrm{H} 12$ and $\mathrm{H}_{3} 21$ to $\mathrm{C} 4(\delta 43.9)$, from $\mathrm{H}_{3} 22(\delta 1.44)$ to $\mathrm{C} 3$ and $\mathrm{C} 9$, from $\mathrm{OH} 9(\delta 5.93)$ to $\mathrm{C} 4$ and $\mathrm{C} 9$ and from $\mathrm{H}_{3} 21$ to $\mathrm{C} 4$ suggested that the cyclohexane ring $\mathrm{B}$ is attached to ring A. 6) The long-range couplings from $\mathrm{H}_{2} 5(\delta 3.14,2.10)$ to $\mathrm{C} 7(\delta 216.6), \mathrm{C} 9$ and $\mathrm{C} 22$, from $\mathrm{H}_{2} 6(\delta 2.82,2.73)$ to $\mathrm{C} 4$ and $\mathrm{C} 8(\delta 55.4)$ and from $\mathrm{H}_{3} 23(\delta 1.42)$ and $\mathrm{H}_{3} 24(\delta 1.31)$ to $\mathrm{C} 7$ and $\mathrm{C} 9$ suggested that the dimethyl cyclohexanone ring $\mathrm{C}$ in the partial structure I is attached to ring B to form the decalin substructure. Based on all the data taken together, the structure of 1 was concluded to be as shown in Fig. 1. The fragment ion peaks of $\mathrm{m} / \mathrm{z} 448,418,236$ and 71 observed in EI-MS (Fig. 3) also supported the structure.

\section{Stereochemistry of Sespendole}

Compound 1 has six chiral carbons in the structure. The relative stereochemistry was elucidated as follows. First, the configurations at $\mathrm{C} 3, \mathrm{C} 4, \mathrm{C} 9$ and $\mathrm{C} 12$ of the decalin moiety (C3 through $\mathrm{C} 12$ ) were deduced from NOE experiments in pyridine- $d_{5}$ as shown in Fig. 4. The NOEs were observed between $\mathrm{H}_{3} 21$ and $\mathrm{OH} 9 / \mathrm{H}_{\mathrm{a}} 11 / \mathrm{H}_{\mathrm{b}} 13$, and between $\mathrm{H}_{3} 22$ and $\mathrm{H}_{b} 10 / \mathrm{H} 12$, suggesting that they are all oriented to axial on a chair conformation of ring B. The NOEs were observed between $\mathrm{H}_{\mathrm{a}} 5$ and $\mathrm{OH} 9$, between $\mathrm{H}_{\mathrm{a}} 6$ and $\mathrm{H}_{3} 23$, and between $\mathrm{H}_{\mathrm{b}} 6$ and $\mathrm{H}_{3} 22$, but not between $\mathrm{H}_{\mathrm{b}} 10$ and $\mathrm{H}_{3} 24$, suggesting that the relative stereochemistry of the decalin moiety is $3 S^{*}, 4 R^{*}, 9 S^{*}$ and $12 S^{*}$ (Fig. 4) and that the ring $\mathrm{C}$ has a twist-boat conformation. Therefore, the geometries at $\mathrm{C} 4$ and $\mathrm{C} 9$ were determined to be trans.

Next, the absolute configuration of the trans-decalin moiety was resolved using optical rotation and circular dichroism experiments [17]. Compound 1 exhibited a negative Cotton effect at around $295 \mathrm{~nm}$ in the CD spectrum due to the $\mathrm{C} 7$ carbonyl group, as shown in Fig. 5A. The relevance of this Cotton effect to the issue of absolute configuration is explainable in terms of the twistboat cyclohexanone [18]. When viewed along the oxygen- 
Table $2{ }^{1} \mathrm{H}$ and ${ }^{13} \mathrm{C}$ NMR chemical shifts of $\mathbf{1}$

\begin{tabular}{|c|c|c|c|}
\hline Position & ${ }^{13} \mathrm{C}$ chemical shift $(\mathrm{ppm})^{\mathrm{a}}$ & & ${ }^{1} \mathrm{H}$ chemical shift $(p p m)^{b}$ \\
\hline 1 & & $\mathrm{NH}$ & $11.46(1 \mathrm{H}$, br.s $)$ \\
\hline 2 & $154.5 \mathrm{~s}$ & & \\
\hline 3 & $53.5 \mathrm{~s}$ & & \\
\hline 4 & $43.9 \mathrm{~s}$ & & \\
\hline \multirow[t]{2}{*}{5} & $29.2 \mathrm{t}$ & $\mathrm{Ha}$ & $3.14(1 \mathrm{H}, \mathrm{ddd}, J=8.0,9.0,13.0 \mathrm{~Hz})$ \\
\hline & & $\mathrm{Hb}$ & $2.10(1 \mathrm{H}, \mathrm{ddd}, J=3.6,7.7,13.0 \mathrm{~Hz})$ \\
\hline \multirow[t]{2}{*}{6} & $35.1 \mathrm{t}$ & $\mathrm{Ha}$ & $2.82(1 \mathrm{H}, \mathrm{ddd}, J=3.6,8.0,15.4 \mathrm{~Hz})$ \\
\hline & & $\mathrm{Hb}$ & $2.73(1 \mathrm{H}, \mathrm{ddd}, J=7.7,9.0,15.4 \mathrm{~Hz})$ \\
\hline 7 & $216.6 \mathrm{~s}$ & & \\
\hline 8 & $55.4 \mathrm{~s}$ & & \\
\hline \multirow[t]{2}{*}{9} & $80.9 \mathrm{~s}$ & & \\
\hline & & $\mathrm{OH}$ & $5.93(1 \mathrm{H}, \mathrm{s})$ \\
\hline \multirow[t]{2}{*}{10} & $31.6 \mathrm{t}$ & $\mathrm{Ha}$ & $1.98(1 \mathrm{H}, \mathrm{ddd}, J=5.0,10.2,13.0 \mathrm{~Hz})$ \\
\hline & & $\mathrm{Hb}$ & $1.94(1 \mathrm{H}, \mathrm{ddd}, J=6.1,9.0,13.0 \mathrm{~Hz})$ \\
\hline \multirow[t]{2}{*}{11} & $21.9 \mathrm{t}$ & $\mathrm{Ha}$ & $2.20(1 \mathrm{H}, \mathrm{dddd}, J=5.0,6.1,13.1,16.8 \mathrm{~Hz})$ \\
\hline & & $\mathrm{Hb}$ & $1.70(1 \mathrm{H}$, dddd, $J=2.6,9.0,10.2,16.8 \mathrm{~Hz})$ \\
\hline 12 & $50.1 d$ & & $2.98(1 \mathrm{H}, \mathrm{dddd}, J=2.6,5.8,10.0,13.1 \mathrm{~Hz})$ \\
\hline \multirow[t]{2}{*}{13} & $30.0 t$ & $\mathrm{Ha}$ & $2.76(1 \mathrm{H}, \mathrm{dd}, J=10.0,12.5 \mathrm{~Hz})$ \\
\hline & & $\mathrm{Hb}$ & $3.07(1 \mathrm{H}, \mathrm{dd}, J=5.8,12.5 \mathrm{~Hz})$ \\
\hline 14 & $116.6 \mathrm{~s}$ & & \\
\hline 15 & $126.5 \mathrm{~s}$ & & \\
\hline 16 & $131.6 \mathrm{~s}$ & & \\
\hline 17 & $130.2 \mathrm{~s}$ & & \\
\hline 18 & $120.5 d$ & & $7.59(1 \mathrm{H}, \mathrm{d}, J=8.5 \mathrm{~Hz})$ \\
\hline 19 & $110.6 \mathrm{~d}$ & & $7.48(1 \mathrm{H}, \mathrm{d}, J=8.5 \mathrm{~Hz})$ \\
\hline 20 & $141.1 \mathrm{~s}$ & & \\
\hline 21 & $17.6 q$ & & $1.75(3 \mathrm{H}, \mathrm{s})$ \\
\hline 22 & $22.6 q$ & & $1.44(3 \mathrm{H}, \mathrm{s})$ \\
\hline 23 & $23.5 q$ & & $1.42(3 \mathrm{H}, \mathrm{s})$ \\
\hline 24 & $24.6 \mathrm{q}$ & & $1.31(3 \mathrm{H}, \mathrm{s})$ \\
\hline \multirow[t]{2}{*}{25} & $29.6 \mathrm{t}$ & $\mathrm{Ha}$ & $4.29(1 \mathrm{H}, \mathrm{dd}, J=6.5,15.5 \mathrm{~Hz})$ \\
\hline & & $\mathrm{Hb}$ & $4.07(1 \mathrm{H}, \mathrm{brd}, J=15.5 \mathrm{~Hz})$ \\
\hline 26 & $126.5 d$ & & $5.56(1 \mathrm{H}, \mathrm{dt}, J=1.0,6.5 \mathrm{~Hz})$ \\
\hline 27 & $131.2 \mathrm{~s}$ & & \\
\hline 28 & $18.4 \mathrm{q}$ & & $1.83(3 \mathrm{H}, \mathrm{brs})$ \\
\hline 29 & $25.7 q$ & & $1.65(3 \mathrm{H}, \mathrm{brs})$ \\
\hline \multirow[t]{2}{*}{30} & $71.2 d$ & & $5.32(1 \mathrm{H}, \mathrm{dd}, J=3.6,8.0 \mathrm{~Hz})$ \\
\hline & & $\mathrm{OH}$ & $7.18(1 \mathrm{H}, \mathrm{d}, J=3.6 \mathrm{~Hz})$ \\
\hline 31 & $69.5 d$ & & $3.88(1 \mathrm{H}, \mathrm{d}, J=8.0 \mathrm{~Hz})$ \\
\hline 32 & $58.7 \mathrm{~s}$ & & \\
\hline 33 & $19.9 q$ & & $1.39(3 \mathrm{H}, \mathrm{s})$ \\
\hline 34 & $25.3 q$ & & $1.37(3 \mathrm{H}, \mathrm{s})$ \\
\hline
\end{tabular}

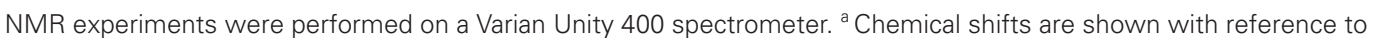
$\mathrm{C}_{5} \mathrm{D}_{5} \mathrm{~N}$ as $149.9 \mathrm{ppm} .{ }^{\mathrm{b}}$ Chemical shifts are shown with reference to $\mathrm{C}_{5} \mathrm{D}_{5} \mathrm{~N}$ as $8.71 \mathrm{ppm}$. 


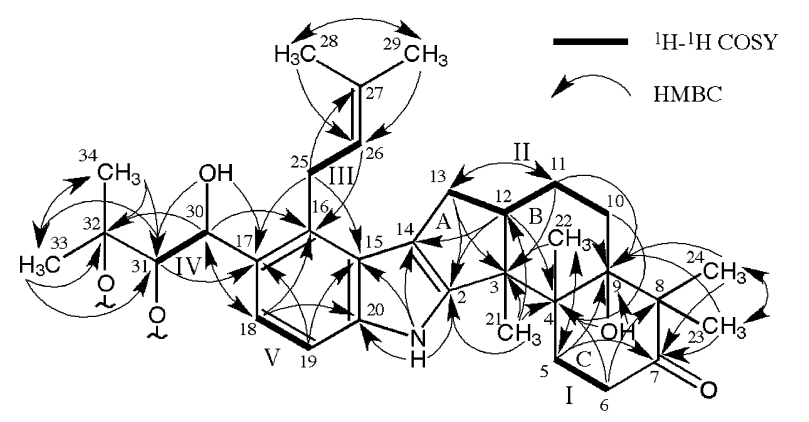

Fig. $2{ }^{1} \mathrm{H}_{-}{ }^{1} \mathrm{H}$ COSY and $\mathrm{HMBC}$ experiments for $\mathbf{1}$.

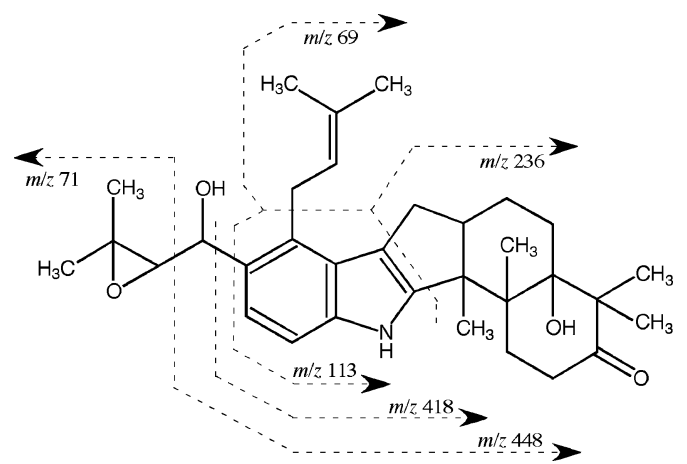

Fig. 3 El-MS fragmentations of $\mathbf{1}$.

carbon axis at the $\mathrm{C} 7$ position, the $\mathrm{C} 7-\mathrm{C} 4$ axis of cyclohexanone (ring $\mathrm{C}$ ) is located on the left side of the carbonyl group (Fig. 5B). Therefore, the absolute stereochemistry of the trans-decalin moiety is presumed to be $3 S, 4 R, 9 S$ and $12 S$.

These conclusions were supported by the modified Mosher method [19] using the ${ }^{1} \mathrm{H}$ NMR chemical shift differences between the $(R)$ - and $(S)$-MTPA esters. Reduction of $\mathbf{1}$ with $\mathrm{NaBH}_{4}$ gave $7 S^{*}$-hydroxy-1 (2a) and $7 R^{*}$-hydroxy-1 (2b) in a 2:3 ratio, which was supported by NOESY experiments as shown in Fig. 6. Then 2a was treated with both $(R)-(-)$ and $(S)-(+)-\alpha$-methoxy- $\alpha$ (trifluoromethyl)phenylacetic acid chloride (MTPACl) and the products were subjected to ${ }^{1} \mathrm{H}-\mathrm{NMR}$ analysis. As shown in Fig. 7, the $\Delta \delta$ values $\left(\delta_{S}-\delta_{R}\right)$ of $\mathrm{H}_{2} 10, \mathrm{H}_{2} 11, \mathrm{H}_{2} 12, \mathrm{H} 21$, $\mathrm{H}_{3} 23, \mathrm{H}_{3} 24$ and $\mathrm{OH} 9$ were positive, while the $\Delta \delta$ values $\left(\delta_{S}-\delta_{R}\right)$ of $\mathrm{NH}, \mathrm{H}_{2} 5, \mathrm{H}_{2} 18, \mathrm{H}_{2} 19$ and $\mathrm{H}_{2} 22$ were negative, indicating that the absolute configuration of C7 in $\mathbf{2 a}$ is $S$. Accordingly, the absolute configurations of the four chiral centers in the trans-decalin moiety were concluded to be $3 S, 4 R, 9 S$ and $12 S$, as shown in Fig. 1.

The stereochemistries of $\mathrm{C} 30$ and $\mathrm{C} 31$ could not be determined on the basis of NOE data and the coupling constant between $\mathrm{H} 30$ and $\mathrm{H} 31 \quad\left(8.0 \mathrm{~Hz}, 130^{\circ}\right)$.
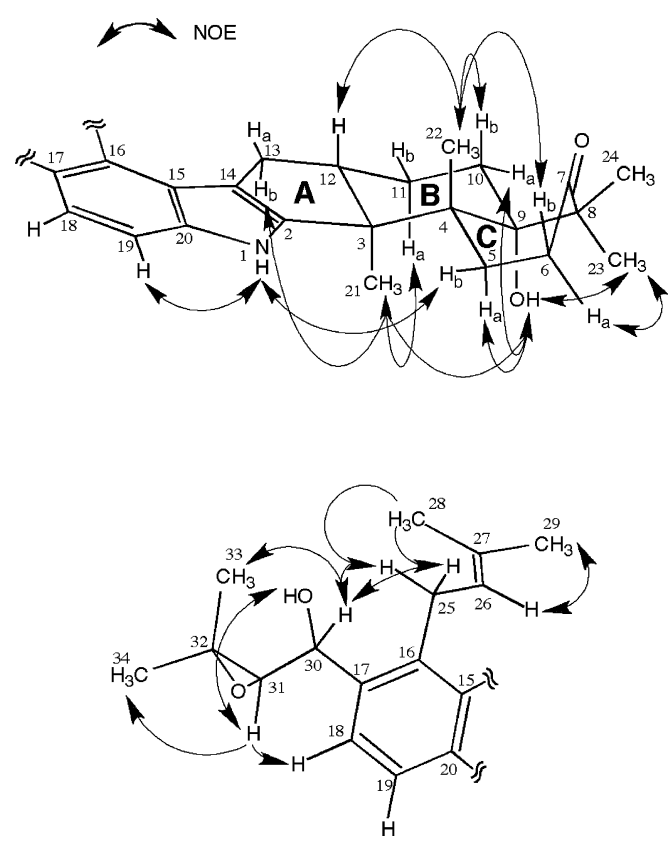

Fig. 4 NOE experiments for 1 measured in pyridine- $d_{5}$.

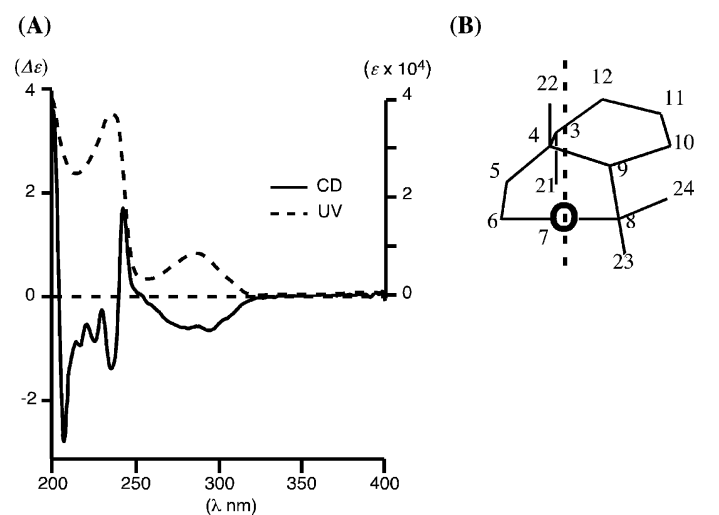

Fig. 5 Optical rotation and circular dichroism experiments for 1 .

(A) CD and UV spectra of 1. (B) Projection drawing of 1 viewed along the oxygen-carbon axis at the $\mathrm{C} 7$ position.

Derivatization of $\mathrm{OH} 30$, located at the para-position to the indole nitrogen, with MTPACl was not successful because of the unfavorable elimination, presumably due to effect of electron-withdrawing residues such as MTPA acid. Therefore, the method using Europium shift reagents in NMR measurement was applied to determine the stereochemistry at C30. Europium tris[3-(heptafluoropropylhydroxymethylene)-( \pm )-camphorate] $\left(\mathrm{Eu}(\mathrm{hfc})_{3}\right)$ [20], which form chelate complexes with hydroxy groups, generally induce a down-field shift of the proton signals located near the hydroxy group. As shown in Fig. 8, the 


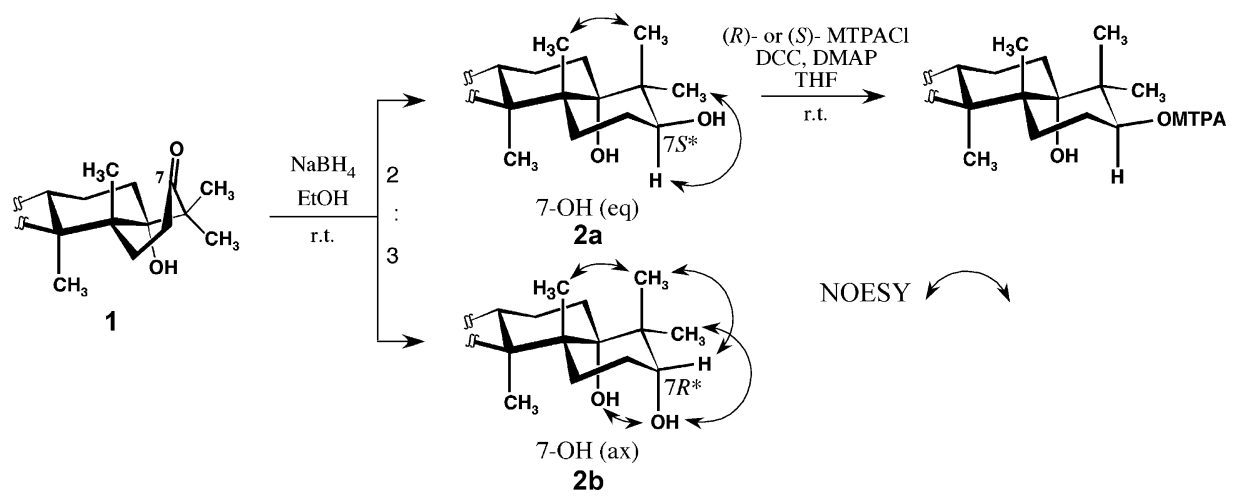

Fig. 6 Preparation of the (R)- and (S)-MTPA ester derivatives of $\mathbf{2 a}$ and NOESY experiments for $\mathbf{2} \mathbf{a}$ and $\mathbf{2} \mathbf{b}$.

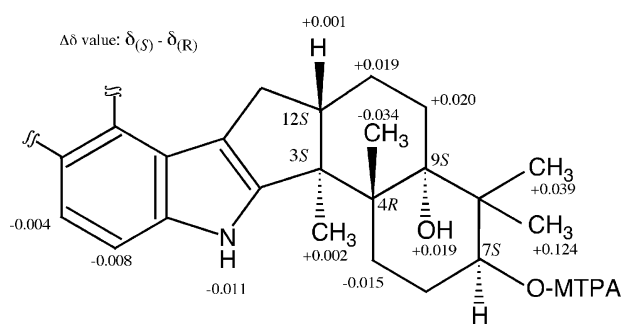

Fig. $7 \Delta \delta$ values $\left[\Delta \delta\right.$ (in ppm) $\left.=\delta_{S}-\delta_{R}\right]$ obtained for the $(R)-(-)$ and $(S)-(+)-$ MTPA esters of $\mathbf{2 a}$.

chemical shifts of $\mathrm{H} 30$ and $\mathrm{H} 31$ in $\mathbf{1}$ were shifted downfield in the presence of $(-)-E u(h f c)_{3}(59$ meq), whereas $(+)-E u(h f c)_{3}(64 \mathrm{meq})$ did not induce a chemical shift change. These data strongly suggested that the absolute stereochemistry of $\mathrm{C} 30$ is the $S$-configuration.

Thus, the absolute configurations in $\mathbf{1}$ except for $\mathrm{C} 31$ were determined to be $3 S, 4 R, 9 S, 12 S$ and $30 S$ (Fig. 1).

\section{Experimental}

\section{Spectroscopic Measurements}

Various NMR spectra were obtained with JEOL EX-270 $(270 \mathrm{MHz})$, Varian XL-400 $(400 \mathrm{MHz})$ and Inova 600 $(600 \mathrm{MHz})$ spectrometers. Electron impact mass spectrometry (EI-MS) was conducted on a JEOL JMSAX505H spectrometer. UV-visible and IR spectra were measured with a Beckman DU640 spectrophotometer and a Horiba FT-210 Fourier transform infrared spectrometer, respectively.

\section{Materials}

Sespendole was isolated from the culture broth of the fungal strain Pseudobotrytis terestris FKA-25 [2]. (R)-(-)$\alpha$-methoxy- $\alpha$-(trifluoromethyl)phenylacetic acid chloride,

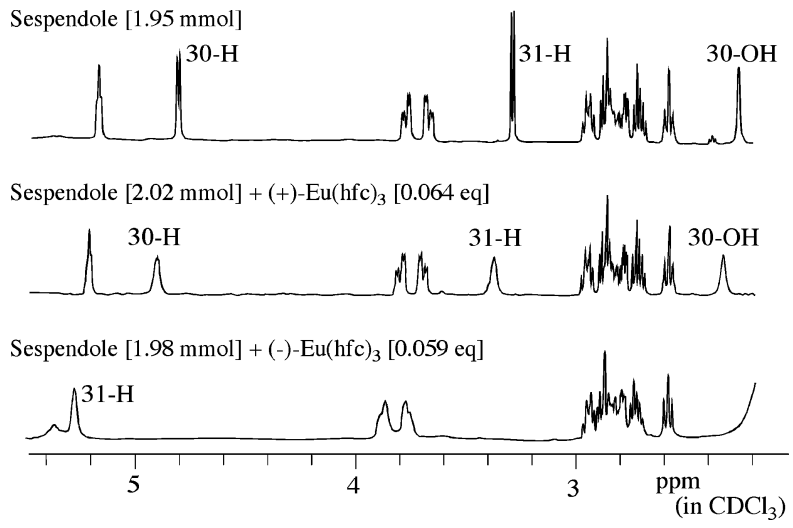

Fig. 8 Stereochemistry of C30 deduced by using chiral shift reagents, Europium tris[3-(heptafluoropropylhydroxymethylene)-(+)-camphorate] and Europium tris[3-(heptafluoropropylhydroxymethylene)-(-)-camphorate].

$(S)$-(+)- $\alpha$-methoxy- $\alpha$-(trifluoromethyl)phenylacetic acid chloride, Europium tris[3-(heptafluoro-propylhydroxymethylene)-(+)-camphorate] and Europium tris[3-(heptafluoropropylhydroxymethylene)-(-)-camphorate] were obtained from Sigma (USA).

\section{Preparation of $7 S^{*}$-Hydroxy-sespendole (2a) and $7 R^{*}$ - Hydroxy-sespendole (2b)}

To a solution of $\mathbf{1}(5 \mathrm{mg})$ in EtOH $(320 \mathrm{ml})$ was added $1.0 \mathrm{mg}$ of $\mathrm{NaBH}_{4}$. The reaction mixture was stirred at room temperature for 3 hours. EtOAc $(2 \mathrm{ml})$ and $\mathrm{H}_{2} \mathrm{O}(2 \mathrm{ml})$ were added, the organic layer was separated, dried over anhydrous $\mathrm{Na}_{2} \mathrm{SO}_{4}$, filtered and concentrated to dryness to afford a yellow material, which was purified by preparative silica gel TLC with hexane-EtOAc $(1: 2)$ as the developing solvent to obtain $7 S^{*}$-hydroxy-sespendole $(\mathbf{2 a}, 2.1 \mathrm{mg})$ and $7 R^{*}$-hydroxy-sespendole (2b, $\left.3.0 \mathrm{mg}\right)$. 


\section{Preparation of the $(R)$ - and $(S)$-MTPA Ester Derivatives of $2 \mathrm{a}$}

To a solution of $\mathbf{2 a}(1 \mathrm{mg})$ in $\mathrm{CH}_{2} \mathrm{Cl}_{2}(100 \mu \mathrm{l})$ was added $1 \mathrm{mg}$ of 4-(dimethylamino)piridine, $2 \mathrm{mg}$ of dicyclohexylcarbodiimide and $2.5 \mathrm{mg}$ of $(R)-(-)-\alpha$-methoxy- $\alpha$-(trifluoromethyl)phenylacetic acid chloride. The reaction mixture was stirred at room temperature for 3 hours. EtOAc $(2 \mathrm{ml})$ and $\mathrm{H}_{2} \mathrm{O}(2 \mathrm{ml})$ were added, the organic layer was separated, dried over anhydrous $\mathrm{Na}_{2} \mathrm{SO}_{4}$, filtered and concentrated to dryness to afford a yellow material, which was purified by preparative silica gel TLC with hexane EtOAc $(1: 1)$ as the developing solvent to obtain a colorless powder of the ( $R$ )-MTPA ester of $\mathbf{2 a}(0.9 \mathrm{mg})$. Similarly, the $(S)$-MTPA ester of $2 \mathbf{a}(0.8 \mathrm{mg})$ was obtained using $(S)-(+)$ $\alpha$-methoxy- $\alpha$-(trifluoromethyl)phenylacetic acid chloride.

\section{Data of $(R)$-MTPA Ester Derivative of 2}

${ }^{1} \mathrm{H}$ NMR $\left(\mathrm{C}_{5} \mathrm{D}_{5} \mathrm{~N}\right) \delta 11.44(1 \mathrm{H}$, br s, NH), $\delta 7.43(1 \mathrm{H}, \mathrm{d}$, $J=8.5 \mathrm{~Hz}, \mathrm{H} 18), \delta 7.38(1 \mathrm{H}, \mathrm{d}, J=8.5 \mathrm{~Hz}, \mathrm{H} 19), \delta 6.00$ $(1 \mathrm{H}, \mathrm{dd}, J=5.3,11.6 \mathrm{~Hz}, \mathrm{H} 7), \delta 5.66(1 \mathrm{H}, \mathrm{s}, \mathrm{OH} 9), \delta 5.49$ (1H, br.t, $J=5.7 \mathrm{~Hz}, \mathrm{H} 26), \delta 4.66(1 \mathrm{H}, \mathrm{d}, J=8.0 \mathrm{~Hz}, \mathrm{H} 30)$, $\delta 4.10(2 \mathrm{H}$, br d, $J=5.7 \mathrm{~Hz}, \mathrm{H} 25), \delta 3.71(1 \mathrm{H}, \mathrm{d}, J=8.0 \mathrm{~Hz}$, $\mathrm{H} 31), \delta 3.05(1 \mathrm{H}, \mathrm{dd}, J=6.0,15.2 \mathrm{~Hz}, \mathrm{H} 13), \delta 3.00(1 \mathrm{H}$, $\mathrm{m}, \mathrm{H} 12), \delta 2.86(1 \mathrm{H}, \mathrm{dt}, J=4.4,13.4 \mathrm{~Hz}, \mathrm{H} 5), \delta 2.23(2 \mathrm{H}$, $\mathrm{m}, \mathrm{H} 6), \delta 2.12$ (1H, m, H11), $\delta 1.94$ (1H, m, H5), $\delta 1.94$ $(1 \mathrm{H}, \mathrm{m}, \mathrm{H} 10), \delta 1.86$ (3H, br s, H28), $\delta 1.75$ (3H, s, H21), $\delta 1.70(1 \mathrm{H}, \mathrm{m}, \mathrm{H} 11), \delta 1.67$ (3H, br s, H29), $\delta 1.43(3 \mathrm{H}, \mathrm{s}$, $\mathrm{H} 22), \delta 1.28(3 \mathrm{H}, \mathrm{s}, \mathrm{H} 33), \delta 1.18(3 \mathrm{H}, \mathrm{s}, \mathrm{H} 23), \delta 1.34(3 \mathrm{H}$, $\mathrm{s}, \mathrm{H} 34), \delta 1.10(3 \mathrm{H}, \mathrm{s}, \mathrm{H} 24)$.

\section{Data of $(S)$-MTPA Ester Derivative of 2}

${ }^{1} \mathrm{H}$ NMR $\left(\mathrm{C}_{5} \mathrm{D}_{5} \mathrm{~N}\right) \delta 11.55(1 \mathrm{H}$, br s, NH), $\delta 7.43(1 \mathrm{H}, \mathrm{d}$, $J=8.5 \mathrm{~Hz}, \mathrm{H} 18), \delta 7.33(1 \mathrm{H}, \mathrm{d}, J=8.5 \mathrm{~Hz}, \mathrm{H} 19), \delta 6.00$ $(1 \mathrm{H}, \mathrm{dd}, J=5.3,11.6 \mathrm{~Hz}, \mathrm{H} 7), \delta 5.68(1 \mathrm{H}, \mathrm{s}, \mathrm{OH} 9), \delta 5.49$ $(1 \mathrm{H}, \mathrm{brt}, J=5.7 \mathrm{~Hz}, \mathrm{H} 26), \delta 4.66(1 \mathrm{H}, \mathrm{d}, J=7.8 \mathrm{~Hz}, \mathrm{H} 30)$, $\delta 4.10(2 \mathrm{H}, \mathrm{brd}, J=5.0 \mathrm{~Hz}, \mathrm{H} 25), \delta 3.71(1 \mathrm{H}, \mathrm{d}, J=7.8 \mathrm{~Hz}$, $\mathrm{H} 31), \delta 3.05(1 \mathrm{H}, \mathrm{dd}, J=6.1,15.7 \mathrm{~Hz}, \mathrm{H} 13), \delta 3.00(1 \mathrm{H}$, $\mathrm{m}, \mathrm{H} 12), \delta 2.85(1 \mathrm{H}, \mathrm{dt}, J=4.5,13.4 \mathrm{~Hz}, \mathrm{H} 5), \delta 2.18(2 \mathrm{H}$, $\mathrm{m}, \mathrm{H} 6), \delta 2.25$ (1H, m, H11), $\delta 1.94$ (1H, m, H5), $\delta 1.94$ $(1 \mathrm{H}, \mathrm{m}, \mathrm{H} 10), \delta 1.86(3 \mathrm{H}, \mathrm{br} \mathrm{s}, \mathrm{H} 28), \delta 1.75(3 \mathrm{H}, \mathrm{s}, \mathrm{H} 21)$, $\delta 1.71(1 \mathrm{H}, \mathrm{m}, \mathrm{H} 11), \delta 1.67$ (3H, br s, H29), $\delta 1.40(3 \mathrm{H}, \mathrm{s}$, $\mathrm{H} 22), \delta 1.28(3 \mathrm{H}, \mathrm{s}, \mathrm{H} 33), \delta 1.31(3 \mathrm{H}, \mathrm{s}, \mathrm{H} 23), \delta 1.36(3 \mathrm{H}$, $\mathrm{s}, \mathrm{H} 34), \delta 1.14$ (3H, s, H24)

Acknowledgments We express our thanks to Dr. S. Iwasaki, The Kitasato Institute, for useful comments and discussion and also to Ms. N. Sato, Ms. A. Nakagawa and Ms. C. Sakabe, School of Pharmacy, Kitasato University, for measurements of NMR and mass spectra. This work was supported by a grant for Scientific Research on Priority Areas (No. 16073215) and a grant from the 21st Century COE Program from the Ministry of Education, Culture, Sports, Science and Technology, Japan, and a grant from the Hoh-ansha Foundation, Japan.

\section{References}

1. Yamaguchi Y, Masuma R, Kim YP, Uchida R, Tomoda H, Ōmura S. Taxonomy and secondary metabolites of Pseudobotrytis sp. FKA-25. Mycoscience 45: 9-16 (2004)

2. Uchida R, Kim YP, Namatame I, Tomoda H, Ōmura S. Sespendole, a new inhibitor of lipid droplet synthesis in macrophages, produced by Pseudobotrytis terrestris FKA25. J Antibiot 59: 93-97 (2006)

3. Nozawa K. Biologically active indoloditerpenes from Aspergillus and Penicillium. In Proceeding of the 38th Annual Meeting of the Mycological Society of Japan. pp. 10-11 (1994)

4. Springer JP, Clardy J. Paspaline and paspalicine, two indolemevalonate metabolites from Claviceps paspali. Tetrahedron Lett 21: 231-234 (1980)

5. Nozawa K, Nakajima S, Kawai K, Udagawa S. Isolation and structures of indoloditerpenes. Possible biosynthetic intermediates to the tremogenic mycotoxin, paxilline, from Emericella striata. J Chem Soc Perkin Trans I 2607-2610 (1988)

6. Springer JP, Clardy J, Wells M, Cole RJ, Kirksey JW. The structure of paxilline, a tremorgenic metabolite of Penicillium paxilli Bainier., Tetrahedron Lett 16: 2531-2534 (1975)

7. Gallagher RT, Latch GCM, Keogh RG. The janthitrems: Fluorescent tremogenic toxin produced by Penicillium janthinellum isolated from ryegrass pastures. Appl Environ Microbial 39: 272-273 (1980)

8. de Jesus AE, Steyn PS, Van Heerden FR, Vleggaar R. Structure elucidation of the janthitrems, novel tremorgenic mycotoxins from Penicillium janthinellum. J Chem Soc Perkin Trans I 697-701 (1984)

9. Gallagher RT A. D. HAWKES Steyn PS, Vleggaar R. Tremorgenic neurotoxins from perennial ryegrass causing ryegrass staggers disorder of livestock: Structure elucidation of the lolitrem B. J Chem Soc Chem Commun 614-616 (1984)

10. de Jesus AE, Steyn PS, Van Heerden FR, Vleggaar R, Wessels PL, Hull WE. Structure and biosynthesis of the penitrems $\mathrm{A} \sim \mathrm{F}$, six novel tremorgenic mycotoxins from Penicillium crustosum. J Chem Soc Chem Commun 289-291 (1981)

11. de Jesus AE, Steyn PS, Van Heerden FR, Vleggaar R, Wessels PL, Hull WE. Tremorgenic mycotoxins from Penicillium crusotosum: Isolation of penitrem $\mathrm{A} \sim \mathrm{F}$ and the structure elucidation and absolute configuration of penitrem A. J Chem Soc Perkin Trans I 1847-1856 (1983)

12. de Jesus AE, Steyn PS, Van Heerden FR, Vleggaar R, Wessels PL, Hull WE. Tremorgenic mycotoxins from Penicillium crusotosum: Isolation of penitrem $\mathrm{A} \sim \mathrm{F}$ and the structure elucidation and absolute configuration of penitrem 
B F. J Chem Soc Perkin Trans I 1857-1861 (1983)

13. Huang XH, Tomoda H, Nishida H, Masuma R, Ōmura S. Terpendoles, novel ACAT inhibitors produced by Albophoma yamanashiensis. I. Production, isolation and biological properties. J Antibiot 48: 1-4 (1995)

14. Huang XH, Tomoda H, Nishida H, Masuma R, Ōmura S. Terpendoles, novel ACAT inhibitors produced by Albophoma yamanashiensis. II. Structure elucidation of terpendoles A, B, C and D. J Antibiot 48: 5-10 (1995)

15. Tomoda H, Tabata N, Yang DJ, Takayanagi H, Ōmura S. Terpendoles, novel ACAT inhibitors produced by Albophoma yamanashiensis. III. Production, isolation and structure elucidation of new components. J Antibiot 48: 793-804 (1995)

16. Uchida R, Tomoda H, Ōmura S. Biosynthesis of sespendole, having an indolosesquiterpene skeleton, produced by Pseudobototytis terrestris FKA-25. J Antibiot 59: 298-302 (2006)

17. Mitchell S, Veitch J. Rotatory-dispersion measurements with a Unicam spectrophotometer. Nature 168: 662-663 (1951)

18. Adachi K, Naemura K, Nakazaki M. The synthesis and the absolute configuration of optically active tricyclo[4.4.0.03.8]decane. Tetrahedron Lett 9: 5467-5470 (1968)

19. Ohtani I, Kusumi T, Kashman Y, Kakisawa H. High-field FT NMR application of Mosher's method. The absolute configurations of marine terpenoids. J Am Chem Soc 113: 4092-4096 (1991)

20. Imai H. Shift reagents of NMR signals (in Japanese). The Chemical Times (Kanto Chemical Co., Inc.) 156: 14-20 (1995) 